Volume 20 Number 1 June 2020.P.191-211

https://doi.org/10.30603/au.v20i1.696

\title{
Analysis of Financial Ratio on Profitability Level \\ (Return on Equity) in PT. Bank Muamalat Indonesia TBK
}

\author{
1.Wahyudin Maguni, 2. Beti Mulu, 3. H.Muh.Turmudi, \\ 4. Husain Insawan, 5. Fitratin Ni'mah \\ ${ }^{12345 .}$ IAIN Kendari
}

\begin{abstract}
Profitability Ratio is a ratio to measure the level of profit obtained by a company. One of the Islamic banks in Indonesia since 1992, namely Bank Muamalat Indonesia (BMI). Based on financial report data for 2014-2016, BMI experienced a decline in assets, causing a decline in profitability at the bank. Therefore, BMI issued new shares through HMTD (Pre-emptive Rights) to obtain fresh funds in order to meet the shortage of liquidity that had occurred to BMIs for the past 4 years. So this study was conducted to determine what factors affect the level of profitability in BMI since the last 4 years with indicators of assessment, among others: CAR (Capital Adequate Ratio), FDR (Financing Deposit Ratio), NPF (Non Performing Financing), and BOPO (Cost Operations on Operating Income). Based on the results of the analysis in this study, it was found that the indicators that affect the profitability of BMI are Capital Adapty Ratio and Operational Costs to Operating Income with a significance value of 0.012 smaller than 0.05, H1 is accepted and CAR to ROE has a significant effect and a significance value of 0.005 smaller than 0.05 then $H 4$ is accepted and BOPO of ROE has a significant effect.
\end{abstract}

\section{Analisis Rasio Keuangan terhadap Tingkat Profitabilitas (Return on Equity) di PT. Bank Muamalat Indonesia TBK}

\begin{abstract}
Abstrak
Rasio Profitabilitas adalah rasio untuk mengukur tingkat laba yang diperoleh perusahaan. Salah satu bank syariah di Indonesia sejak 1992, yaitu Bank Muamalat Indonesia (BMI). Berdasarkan data laporan keuangan untuk 2014-2016, BMI mengalami penurunan aset, menyebabkan penurunan profitabilitas di bank. Oleh karena itu, BMI menerbitkan saham baru melalui HMTD (Hak Memesan Efek Terlebih Dahulu) untuk mendapatkan dana segar guna memenuhi kekurangan likuiditas yang terjadi pada BMI selama 4 tahun terakhir. Maka penelitian ini dilakukan untuk mengetahui faktor apa saja yang mempengaruhi tingkat profitabilitas pada BMI sejak 4 tahun terakhir dengan indikator penilaian, antara lain: CAR (Capital Adequate Ratio), FDR (Financing Deposit Ratio), NPF (Non Performing Financing), dan BOPO (Biaya Operasi pada Pendapatan Operasional). Berdasarkan hasil analisis dalam penelitian ini, ditemukan bahwa indikator yang mempengaruhi profitabilitas BMI adalah Capital Adapty Ratio dan Biaya Operasional terhadap Pendapatan Operasional dengan nilai signifikansi 0,012 lebih kecil dari 0,05, H1 diterima dan CAR to ROE memiliki pengaruh signifikan dan nilai signifikansi 0,005 lebih kecil dari 0,05 maka H4 diterima dan BOPO ROE memiliki pengaruh signifikan.
\end{abstract}

Kata Kunci: Financial Ratio, Profitability Level and ROE

Author correspondence

Email: wmaguni@yahoo.com, Available online at http://journal.iaingorontalo.ac.id/index.php/au/index 


\section{A. Introduction}

There are several financial ratios to measure the financial position of a bank, the measurement is intended so that investors can easily make decisions to invest in the bank. According to J. Fred Weston, these financial ratios include Liquidity Ratios, Profitability Ratios, Ratios ${ }^{1}$

Solvability, Activity Ratio, Growth Ratio, and Rating Ratio.11 Bank Indonesia has issued a regulation regarding guidelines for assessing bank soundness in Circular Letter No.6 / 10 / PBI / 2004 dated 12 April 2004 using CAMELS analysis (Capital, Asset, Management, Earning, Liquidity, Sensitivity to Market Risk). ${ }^{2}$

This study uses several aspects that exist in the CAMEL analysis in calculating the level of profitability of Islamic banks with the intended aspects, namely Capital covering CAR, Asset includes important information is profit. This information is very important because it explains how the company performs for a period from the past period. The financial statements used in this study are financial statements from Bank Muamalat Indonesia. The bank was chosen because the bank was the first Islamic bank in Indonesia and became the only bank capable of surviving during the economic crisis that hit Indonesia in NPF, Management includes BOPO, and Liquidity including FDR. Profitability ratio with several ratios in question, used to predict bank bankruptcy, to assess the soundness of the bank, and assess the performance of the bank in terms of the profits that the bank has obtained.

The main data on which this research is based are financial statements. The parties with an interest in financial statements are investors, employees, lenders (creditors), the government, Bank Indonesia, the Financial Services Authority, and the community as customers who will invest in the bank. Financial statements are presented to fulfill different information. One of in 1998. Based on the financial statements of Bank Muamalat Indonesia over the past 3 years, namely 2014-2016, there was a significant decline in assets.

\footnotetext{
1 Kasmir, Analisis Laporan Keuangan, (PT. Rajawali Pers, 2014) hal.106

2 Surat Edaran Bank Indonesia No.12/ 11 /DPNP tanggal 31 Maret 2014 tentang panduan dalam menilai tingkat kesehan bank dengan analisis CAMELS
} 
Ficture: 1.Graph of Total Assets from Bank Muamalat ${ }^{3}$

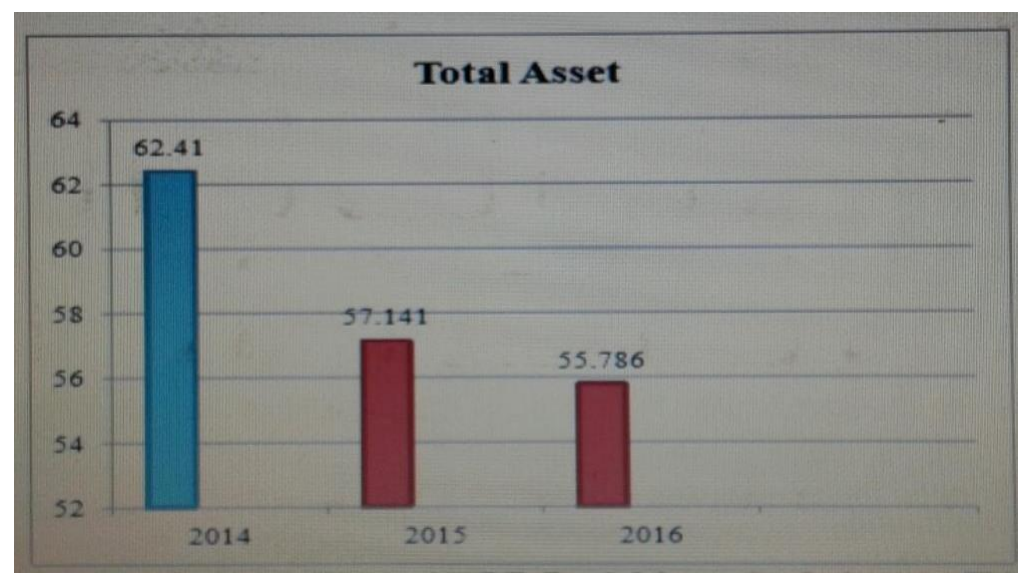

\section{Source: Financial Report of PT. Bank Muamalat Indonesia Tbk.2018}

The table shows that the total assets of Bank Muamalat decreased from the previous 3 years, namely knowing 2014 as much as 62.41 billion to 55.786 billion. The decline in these assets adversely affected the health of Bank Muamalat. ${ }^{4}$ The impact has an impact on customers who no longer trust the bank, resulting in an increase in NPF or the amount of bad credit risk. 2017 is recorded in the quarterly financial statements of Bank Muamalat Indonesia that NPF (Net Performing Financing) has increased to reach $4 \%$. This value is close to the maximum NPF figure set by Bank Indonesia at 5\% per year. When compared with NPF in the last 3 years, BMI has reached an average value of 8.01 per year.

Even though the value of CAR or the value of capital adequacy in BMI tends to be in a very healthy position, BMI is not able to manage finances to the full. So that it caused Bank Muamalat to experience a shortage of assets. Based on this, Bank Muamalat sells more than $50 \%$ of the assets he has to obtain additional capital. Bank Muamalat increased capital by issuing new shares through the Preemptive Rights (HMTD) scheme.

The asset was successfully owned by a brokerage company namely Minna Padi with $51 \%$ or 80 billion shares with a value of 4.5 billion which had previously been a standby buyer. Minna Padi officially acquired Bank Muamalat with the

\footnotetext{
3 www.bankmuamalat.co.id

${ }^{4}$ Laporan Tahunan 2014 Annual Report "Building Opimism Amidst Market Challenge” PT. Bank Muamalat Indonesia Tbk
} 
majority share. 33 Minna Padi or PT. ${ }^{5}$ Minna Padi Securitas Tbk. is a brokerage company that is listed on the Indonesia Stock Exchange which is engaged in securities trading on duty as an intermediary for customers in purchasing securities.44 This company is an Indonesian company. ${ }^{6}$

Based on the description above, it becomes the reference material in this study, why Bank Muamalat Indonesia, which is the first Islamic bank in Indonesia, can experience this. Therefore the researcher conducted a research on the level of profitability in the BMI submitted in the form of a research proposal entitled "The Effect of CAR (Current Asset ratio), FDR (Financing Deposit Ratio), NPF (Non Performing Financing), and BOPO (Operating Income Operating Costs) to the level of Profitability (Return On Equity) at PT. Bank Muamalat Indonesia Tbk ".

\section{B. Literature Review}

Sri Windarti and Misbach Fuady in the research written in the EBBANK Journal entitled "Factors Affecting Profitabilias Sharia Commercial Banks in Indonesia" explained that the factors that affect profitability in Indonesia are CAR, KAP (Earning Assets Quality), BOPO, REO (Operational Efficiency Ratio), FDR, and GWM (Minimum Required Current Account). With the results of the CAR variable research has a significant positive effect on the Syariah Commercial Bank Profitability. Significance value 0.00105 and t-Statistic 2.622824 indicate that an increase in capital is proven to be followed by an increase profitability of Islamic banks. KAP has a significant negative effect on profitability in Islamic Commercial Banks. $^{7}$

Wawan Prasetyo in his research on Analysis Affecting Banking Profitability stated that CAR did not affect bank profitability. In addition, the BOPO variable has an influence on bank profitability. The smaller the value of BOPO means the more efficient the operational costs incurred. ${ }^{8}$

5 www.republika.co.id

6 www.minnapadi.com

7 Sri Windarti Mokoagow dan Misbach Fuady, Faktor - Faktor yang mempengaruhi profitabiltas bank umum syariah di Indonesia, Jurnal EBANK Vol. 6. No. 1. Hal. 33-62, 2015.

${ }^{8}$ www.google.com/search.Wawan+Prasetyo.Analysis,Affecting+Banking,Profitability, stated that CAR,did not affect bank profitability. In addition the BOPO 
Analysis of Financial Ratio on Profitability Level (Return on Equity) in PT. Bank Muamalat Indonesia TBK

Affecting the Profitability of Islamic Banks. The results showed that financing had a direct effect on profitability of 2.45\%. Net Interest Margin (NIM) has a direct effect on Profitability of 6.45\%. Non Performing Finance (NPF)

Direct influence on profitability of $4.32 \%$. Financing has an indirect effect on Non Performing Finance (NPF) of 2.77\%. Net Interest Margin (NIM) has an indirect effect on Non Performing Finance (NPF) of 2.77\%.

Management journal entitled "The Influence of CAR, FDR, and BOPO on Profitability (Empirical Study on Sharia Commercial Banks in Indonesia Period 2009-2013)".9 The results showed that CAR, FDR, NPF, and BOPO variables simultaneously had a significant influence on the ROE of Sharia Commercial Banks.

\section{ROE (Return On Equity)}

The profitability ratio is a ratio to assess the company's ability to seek profits. This is indicated by profits generated from sales and investment income. The point is the use of this ratio shows company efficiency. 10 The measure of profitability in the banking industry in general is Return on Equity (ROE) and Return On Assets (ROA). ROA focuses on the company's capabilities to obtain earnings in its operations, whereas Return On Equity (ROE) only measures returns obtained from investment of company owners in the business. ${ }^{11}$ The results of returns on equity or profitability of own capital indicate the efficiency of the use of own capital. This means that the position of the company owner is getting stronger, and vice versa. Furthermore, the increase will cause an increase in bank stock prices. Mathematically ROE can be formulated as a bank account:

$$
\text { ROE }=\frac{\text { Return }}{\text { Totsl Equity }} x 100
$$

\section{CAR (Capital Adequacy Ratio)}

CAR or Capital Ratio is assessment of bank capital adequacy to cover current risks and anticipate future risks. The higher the CAR, the higher the ROE. In accordance with Bank regulations Indonesia No.6 / 10 / PBI / 2010 concerning the

${ }^{9}$ Aulia, Farrashita dan Prasetiono, Pengaruh CAR, FDR, dan BOPO terhadap Profitabilitas (Studi Empiris pada Bank Umum Syariah di Indonesia Periode Tahun 2009-2013), Diponegoro Journal of Management Vol. 5 No. 1 hal. 1-10, 2016

10 Kasmir, Analisis Laporan Keuangan. Edisi Satu, Cetakan Ketujuh. (Jakarta : PT Raja Grafindo Persada, 2014) hal. 196

11 Dahlan, Manajemen Lembaga Keuangan, Edisi Ketiga, (Jakarta: Fakultas Ekonomi Indonesia, 2001) hal. 86 
Soundness Rating System for Commercial Banks, the higher the CAR value indicates the healthier the bank, but CAR that is too high means that there are idle funds. Thus, the opportunity for banks to obtain profits will decrease; consequently it will reduce the profitability of the bank.

$$
C A R=\frac{\text { modal sendiri }}{\text { ATMR }} X 100
$$

3. FDR (Financing Deposit Ratio) Financing to Deposit Ratio is the ability of banks to channel funds to parties in need capital. ${ }^{12}$ FDR describes the comparison between the amount of the loan or the financing given to the customer and the amount of funds collected by the Islamic bank. The greater the amount of funds channeled to customers in the form of credit, then the amount of unemployed funds decreases and the income earned will increase. This of course will increase FDR so that bank profitability also increases. According to Bank Indonesia Circular Number 13/27 / DPM On 1 December 2011, the FDR ratio formula is as follows:

$$
F D R=\frac{\text { jumlah pemb.yg.disalurkan }}{\text { total deposit }} \times 100
$$

4. NPF (Non Performing Financing) NPF is the rate of return credit / financing provided by depositors to banks, in other words NPF / NPL is the level of bad credit at the bank. If the NPF gets lower, then the bank will experience more profits. Conversely, if the NPF level is high, the bank will suffer losses due to the return on bad loans. Bank Indonesia has set an NPF limit of 5\%. If a bank's NPF can be reduced below $5 \%$, the potential profit gained will be even greater because the bank can save money that is used to form reserves of non-performing loans or Allowance for Earning Assets (PPAP). It can be concluded that the greater the NPF ratio, the greater the risk borne by the company and later it will also negatively affect profitability.The formulaition is:

$$
N P F=\frac{\text { jumlah pembiayaan bermasalah }}{\text { total pembiayaan }} \times 100
$$

\section{BOPO (Oprasional Cost of Operational Income)}

This ratio is a comparison between operational costs and operating income. The operational cost ratio is used to measure the level of efficiency and ability of banks in conducting operations.

\footnotetext{
12 Kasmir, Analisis Laporan Keuangan, (PT. Rajawali Pers, 2008) hal.151
} 
Analysis of Financial Ratio on Profitability Level (Return on Equity) in PT. Bank Muamalat Indonesia TBK

$$
\text { BOPO }=\frac{\text { biaya operasional }}{\text { total deposit }} \times 100
$$

If the ratio increases, it reflects the lack of ability of banks to reduce operating costs and increase their operating income which can cause losses because banks are less efficient in managing their business.

\section{Methods, Data, and Analysis}

This type of research is quantitative descriptive research that explains the relationship between dependent variables and independent variables. Quantitative Research is a process of finding knowledge that uses data in the form of numbers as a tool to analyze. The method in this study uses multiple regression analysis, ${ }^{13}$ which is intended to test the effect of CAR, NPF, FDR, and BOPO on the level of profitability of PT. Bank Muamalat Indonesia Tbk.

The data used is sourced from quarterly Financial Reports from 2014-2017 PT. Bank Muamalat Tbk obtained from the research object website and OJK (Financial Services Authority). This study uses 5 variables. 1 Dependent Variables namely ROE and 4 Independent Variables, namely CAR, FDR, NPF, BOPO. ${ }^{14}$

The method of data analysis is done by using Multiple Analyses Regression performed on SPSS 21 and Microsoft Excel with formulations:

$$
\mathrm{Y}=\mathrm{b} 0+\mathrm{b} 1 \mathrm{X} 1+\mathrm{b} 2 \mathrm{X} 2+\mathrm{b} 3 \mathrm{X} 3+\mathrm{b} 4 \mathrm{X} 4+\mathrm{e}
$$

\section{Information:}

$\mathrm{X} 1=\mathrm{CAR}$

$\mathrm{X} 2=\mathrm{FDR}$

$\mathrm{X} 3=\mathrm{NPF}$

$\mathrm{X} 4=\mathrm{BOPO}$

$\mathrm{Y}=\mathrm{ROE}$

b0 $=$ Kostan Number

b1, b2...Bn = Regression Coefficient

$\mathrm{e}=$ Error $/$ Error Factor

Another analysis used is the test classical assumptions (normality test, autocorrelation test, and multicollinearity test) on the research variable. In the

13 Kasiram, Moh. Metodologi Penelitian. (Malang: UIN-Malang Pers, 2008) hal. 149

14 Laporan Tahunan 2014 Annual Report "Building Opimism Amidst Market Challenge" PT. Bank Muamalat Indonesia Tbk 
event of a deviation from the classical assumption, the $t$ test and $F$ test to be conducted are invalid and can statistically confuse the conclusions obtained.

\section{Normality Test}

Normality test in the regression model used to test whether the residual value is normally distributed or not. Using the Normal P-P chart Plot of regression standardized residuals and the Kolmogorov Smirnov statistical method If the value of Asymp. Sig 2-tailed $>0.05$ then $\mathrm{H} 0$ is rejected and residuals are spread normally. Conversely if Asymp. Sig 2-tailed $<0.05$, H0 is accepted and residual spread is not normal.

\section{Autocorrelation Test}

Autocorrelation occurs when the disturbance value in a certain period is related to previous disturbance value. The simplest autocorrelation test is to use the Durbin-Watson (DW) test. The decision making on the test Durbin Watson is:
a. DW $<1.1$ : There is autocorrelation
b. $1.1<\mathrm{DW}<1.54$ : None
Clear conclusion
c. $1.55<\mathrm{DW}<2.46$ : None

\section{Autocorrelation}

d. $2.46<\mathrm{DW}<2.9$ : None clear conclusion

e. $D W>2.91$ : There is autocorrelation

\section{Multicollinearity Test}

This test aims to test whether in the regression model found a correlation between independent variables. the independent variable does not have a correlation. To detect the presence or absence of multicollinearity in a regression model can be seen from tolerance value or variance inflation factor (VIF). So the low tolerance value is the same as the high VIF value. The commonly used cutoff value is:

a. If the tolerance value is $>10 \%(0,1000)$ and VIF value is $<10$, then there is no Multicollinearity between independent variables in the regression model. 
b. If the tolerance value is $<10 \%(0,1000)$ and VIF value is $>10$, then there is multicolonearity between the independent variables in the regression model.

\section{Correlation Test}

Correlation analysis (Bivariate Correlation) is used to determine the closeness of the relationship between two variables and to find out the direction of the relationship that occurs. A simple correlation coefficient shows how big the relationship is that occurs between two variables. With guidelines for degree of relationship:
a. Pearson Correlation Value $0.00-0.20=$ no correlation
b. Pearson Correlation Value $0.21-0.40=$ weak correlation
c. Pearson Correlation Value $0.41-060=$ medium correlation
d. Pearson Correlation Value $0.61-0.80=$ strong correlation
e. Pearson Correlation Value $0.81-1.00=$ perfect correlation

with values marked positive and negative indicating the direction of the relationship. A positive sign indicates the direction of a unidirectional relationship while for a negative sign indicates an opposite relationship.

\section{Test the Hypothesis}

The $t$ statistical test shows how far the influence of one independent variable individually in explaining the dependent variable. The results of the test can be known by comparing the p-value with $\alpha$ of 0.05 or comparing t-count and $t$ table, if $\mathrm{p}$-value $<0.05$ or $\mathrm{t}$-count $>\mathrm{t}$-table, it can be concluded that $\mathrm{H} 0$ refused. Likewise vice versa if $\mathrm{p}$-value $>0.05$ or $\mathrm{t}$-count $<\mathrm{t}$-table then $\mathrm{H} 0$ is accepted.

The $\mathrm{F}$ statistic test is a test of the overall regression coefficient. If the probability (significance) $>0.05(\alpha)$ or $\mathrm{F}$ count $<\mathrm{F}$ table means the hypothesis is not proven then $\mathrm{HO}$ is accepted $\mathrm{Ha}$ is rejected if done simultaneously. If the probability (significance) $<0.05(\alpha)$ or F count $>\mathrm{F}$ table means that the hypothesis is proven then $\mathrm{HO}$ is rejected and $\mathrm{Ha}$ is accepted if done simultaneously.

The coefficient of determination is a test carried out to see how much influence the independent variable can explain the variable dependent. That is by looking at the adjusted $\mathrm{R}$ squared, if the adjusted $\mathrm{R}$ squared is greater than the 
value 1 means that the independent variable chosen can explain the dependent variable.

\section{Research Result}

1. Normality Test

From the graph above, it can be seen that the points spread around the line and follow the diagonal line, it is concluded that the residual value is normal.

\section{Picture:2}

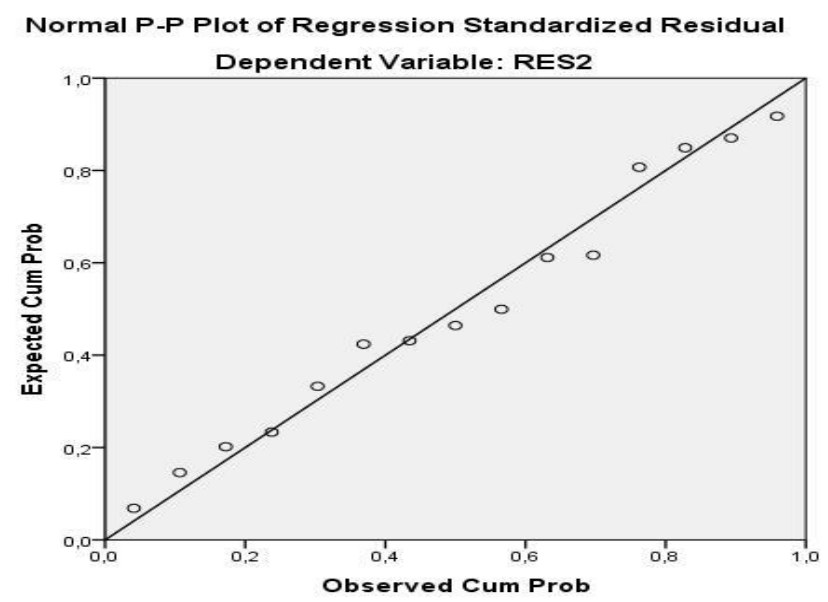

However, this test is not accurate, so another normality test is tested, using the Kalmograv Smirnov statistical method. The results of the Kolmogorov-Smirnov normality test can be seen in the following table:

Table:

Kalmograv Smirnovrr Test Results

Table: 1 One-Sample Kolmogorov-Smirnov Test

\begin{tabular}{|ll|r|}
\hline & & $\begin{array}{r}\text { Unstandardized } \\
\text { Residual }\end{array}$ \\
\hline Normal & Mean & 15 \\
Parametersa,b & Std. Deviation &, 98256941 \\
Most Extreme & Absolute &, 180 \\
Differences & Positive &, 180 \\
& Negative &,- 122 \\
Test Statistic & &, 180 \\
Asymp. Sig. (2-tailed) & &, $200^{c, d}$ \\
\hline
\end{tabular}



a. The distribution test is Normal.
b. Calculated from data.

\section{Source: SPSS data, 2018}

In the table above shows that the variables CAR, FDR, NPF, BOPO, and ROE indicate that the value of Asymp. Sig ( 2 tailed)> 0.200. Overall, the variables are normally distributed.

2. Autocorrelation Test

The Autocorrelation Test Results are as follows:

Table: 2. Autocorrelation Test Results, Summary b model

\begin{tabular}{|r|c|c|c|c|}
\hline Model & $\mathbf{R}$ & $\mathrm{R}$ & Adjusted & Durbin \\
& & Square & R Square & Watson \\
\hline 1 &, $769^{\mathrm{a}}$ &, 592 &, 428 & 2,555 \\
\hline
\end{tabular}

a. Predictors: (Constant), BOPO, FDR, NPF, CAR

b. Dependent Variable: RES2

\section{Source: SPSS data, 2018}

From the table above, we can see the results of the autokorelai test with the value of Durbin Watson Amounting to 2.555. The DW value will be compared with the table value by using a $5 \%$ confidence level, with a sample of 15 out of 4 independent variables. Then from the Durbin Watson table (attached) there will be a ld. value of 0.685 and a value of dU 1.977 .

3. Multiconearity Test

Table:3 Multicollinearity Test Results Coefficientsa

\begin{tabular}{|c|c|c|c|c|}
\hline & & & \multicolumn{2}{|c|}{ Collinearity } \\
\hline Model & $\mathrm{t}$ & \multirow{2}{*}{ Sig. } & \multicolumn{2}{|c|}{ Statistics } \\
\cline { 3 - 5 } & & & Tolerance & VIF \\
\hline 1 (Cons) & 3,468 & 006 & & 4,625 \\
CAR & $-3,057$ & 012 &, 216 & 1,117 \\
FDR & $-1,003$ & 340 &, 895 & 1,814 \\
NPF &, 784 & 451 &, 551 & 5,957 \\
BOPO & $-3,524$ & 005 &, 168 & \\
& & & & \\
\hline
\end{tabular}


Dependent Variable: ROE

Based on the table above it can be concluded that there is no multiclinearity because each variable has a tolerance value above 0.10 and a VIF value above 10 because it is in accordance with the provisions of the multicollinearity test.

4. Correlation Test

Following are the results of the Pearson Correlation test. Positive and negative signs indicate the direction of the relationship. A positive sign indicates the direction of a unidirectional relationship while for a negative sign indicates an opposite relationship.

Table;4 Hasil Uji Pearson Correlation

\begin{tabular}{|c|c|c|c|c|c|c|}
\hline \multicolumn{7}{|c|}{ Hasil Uji Peaerson Correlation } \\
\hline & & CAR & FDR & NPF & BOPO & ROE \\
\hline \multirow[t]{3}{*}{ CAR } & Pearson Correlation & 1 &,- 173 & -.457 & $-.862^{*+}$ & $.599^{\circ}$ \\
\hline & Sig. (2-tailed) & & .537 & .087 & .000 & .018 \\
\hline & $\mathbf{N}$ & 15 & 15 & 15 & 15 & 15 \\
\hline \multirow[t]{3}{*}{ FDR } & Pearson Correlation &,- 173 & 1 & -.031 & .012 & .101 \\
\hline & Sig. (2-tailed) & .537 & & .913 & 967 & .719 \\
\hline & $\mathbf{N}$ & 15 & 15 & 15 & 15 & 15 \\
\hline \multirow[t]{3}{*}{ NPF } & Pearson Correlation &.,- 457 &,- 031 & 1 & $.642^{*}$ & $-.523^{\circ}$ \\
\hline & Sig. (2-tailed) & .087 & 913 & & .010 & .046 \\
\hline & $\mathbf{N}$ & 15 & 15 & 15 & 15 & 15 \\
\hline BOP & Pearson Correlation &,$- 862^{*}$ & 012 & $.642^{* *}$ & 1 &,$- 688^{* *}$ \\
\hline \multirow[t]{2}{*}{ O } & Sig. (2-tailed) & .000 & $=967$ & $=010$ & & $=005$ \\
\hline & $\mathbf{N}$ & 15 & 15 & 15 & 15 & 15 \\
\hline \multirow[t]{3}{*}{ ROE } & Pearson Correlation &, $599^{\circ}$ & .101 &,$- 523^{*}$ &,$- 688^{* *}$ & 1 \\
\hline & Sig. (2-tailed) & $=018$ & $=719$ & .046 &, 005 & \\
\hline & $\mathrm{N}$ & 15 & 15 & 15 & 15 & 15 \\
\hline
\end{tabular}

Based on $\alpha=0.05$ (5\%) can explained the relationship between variables. ROE and CAR variables have a significant relationship with a significance value of 0.018 and the value of Pearson Correlation 0.599 means that the CAR variable on ROE has a significant relationship because 0.018 is smaller $(<)$ than 0.05 and has a unidirectional correlation that is in the range $0,41-0.60$. 
ROE and NPF variables have significance relationship with a significant value of 0.46 and the Pearson Correlation value of ? 0.523 means

ROE variable has a significant effect on NPF variable because the significance value is smaller than 0.05 with the relationship not in the same direction because it has a negative Pearson Correlation value and is in the medium category with a range of $0.41-0.60$.

Based on $\alpha=0.01$ (1\%) describes several variables that have relationships. These variables include BOPO to CAR, BOPO to NPF, and ROE to BOPO. BOPO variable on CAR has a significant relationship below 0.05 but does not have a direct relationship and the Pearson Correlation value is -0.862 . This means that the BOPO variable on CAR has a significant relationship because it is below 0.05 .

NPF and BOPO variables have a significant relationship with a significant value of 0.10 and the Pearson Correlation value is 0.642 . This means that the variables of the two variables have a significant effect because they have a significant value of 0.10 with the relationship is in line because Pearson Correlation is positive and is in the strong correlation category.

The ROE and BOPO variables have a significant relationship with a significant value of 0.005 and the Pearson Correlation value of -0.688 means the ROE variable has a significant effect on the BOPO variable because the significant value is below 0.05 with a unidirectional relationship because it has a negative Pearson correlation and is in the correlation category strong with a range of $0.61-0.80$.

5. Multiple Linear Regression Analysis This analysis is to find out the direction the relationship between the independent variable and the dependent variable whether each independent variable is related positive or negative and to predict the value of the dependent variable if the value of the independent variable increases or decreases. The following are the results of multiple regression tests: 
Table:5 Multiple Regression Test Results

Coefficientsa

\begin{tabular}{|l|r|r|r|r|r|}
\hline & \multicolumn{2}{|c|}{$\begin{array}{r}\text { Unstandardized } \\
\text { Coefficients }\end{array}$} & $\begin{array}{r}\text { Standr. } \\
\text { Coef. }\end{array}$ & & \\
\cline { 2 - 4 } & Model & $\begin{array}{r}\text { Std. } \\
\text { Error }\end{array}$ & Beta & $\mathrm{t}$ & Sig. \\
\cline { 2 - 4 } CAR & 16,009 & 4,616 & & 3,468 &, 006 \\
FDR &,- 335 &, 110 & $-1,328$ & $-3,057$ &, 012 \\
NPF &,- 019 &, 019 &,- 214 & $-1,003$ &, 340 \\
BOPO &, 039 &, 050 &, 213 &, 784 &, 451 \\
&,- 100 &, 028 & $-1,738$ & $-3,524$ &, 005 \\
\hline
\end{tabular}

\section{a. Dependent Variable: ROE}

\section{Source: SPSS data, 2018}

From the table above the regression equation can be arranged as follows:

$\mathrm{ROE}=16,009+(-0,335) \mathrm{CAR}+(-0,019) \mathrm{FDR}+0,039 \mathrm{NPF}+(-0,100) \mathrm{BOPO}+\mathrm{e}$

The above multiple regression equations can be explained as follows:

a) Constant value of 16.009 means if the value of CAR (X1), FDR (X2), NPF $(\mathrm{X} 3)$, and BOPO $(\mathrm{X})$ is zero $(0)$, then the $\mathrm{ROE}(\mathrm{Y})$ ratio is $16.009 \%$ or $16.01 \%$.

b) CAR variable regression coefficient that is -0.335 means if the value of other independent variables is fixed and CAR has increased by 1\%, the ROE ratio has decreased by $0.335 \%$. The coefficient is negative, meaning there is a negative relationship between CAR and ROE, the higher the CAR ratio the ROE ratio tends to decrease.

c) FDR variable regression coefficient which is - 0.019 means if the value of the other independent variables is fixed and FDR has a $1 \%$ increase in the ratio

ROE decreased by $0.019 \%$. The coefficient is negative, meaning that there is a negative relationship between FDR and ROE, the higher the FDR, the ROE ratio tends to decrease.

d) NPF variable regression coefficient which is 0.039 means that if the value of the other independent variables is fixed and NPF has increased by $1 \%$, the ROE ratio has decreased by $0.039 \%$. The coefficient is positive, meaning 
Analysis of Financial Ratio on Profitability Level (Return on Equity) in PT. Bank Muamalat Indonesia TBK

that there is a positive relationship between NPF and ROE, the higher the NPF, the ROE ratio decreases.

e) BOPO variable regression coefficient which is - 0.1 means if the value of the other independent variables is fixed and NPF has increased by 1\%, the ROE ratio has decreased by $0.1 \%$. The coefficient is negative, meaning that there is a negative relationship between $\mathrm{BOP}$ and $\mathrm{ROE}$, the higher the $\mathrm{BOPO}$, the ROE ratio decreases.

6. Test the Hypothesis

a. Partial Test (statistics t)

This test shows how much far the influence of independent variables

Partial / individual in explaining the dependent variables. Following is the partial test table:

Table:6

Hasil Uji Parsial Variabel CAR, FDR, NPF, BOPO terhadap ROE

Coefficients ${ }^{a}$

\begin{tabular}{|c|c|c|c|c|c|}
\hline \multirow[b]{2}{*}{ Model } & \multicolumn{2}{|c|}{$\begin{array}{c}\text { Unstandardized } \\
\text { Coefficients }\end{array}$} & \multirow{2}{*}{$\begin{array}{c}\text { Standardized } \\
\text { Coefficients } \\
\text { Beta }\end{array}$} & \multirow[b]{2}{*}{$\mathbf{t}$} & \multirow{2}{*}{ Sig. } \\
\hline & B & Std. Error & & & \\
\hline 1 (Constant) & 16,009 & 4,616 & & 3,468 &, 006 \\
\hline CAR &,- 335 &, 110 & $-1,328$ & $-3,057$ &, 012 \\
\hline FDR &,- 019 &, 019 &,- 214 & $-1,003$ &, 340 \\
\hline NPF &, 039 &, 050 &, 213 &, 784 &, 451 \\
\hline BOPO &,- 100 &, 028 & $-1,738$ & $-3,524$ & ,005 \\
\hline
\end{tabular}

Source: SPSS data, 2018

Based on the table above, it can be explained that the testing of the first hypothesis is $\mathrm{H} 1$ = CAR has a significant effect on ROE with a regression coefficient of -0.335 . The estimation result of CAR variable is $t$ table value $=-3,057$ and the probability value or $t$ count is 0,012 . Significance value of 0.012 is smaller than 0.05, H1 is accepted and CAR to ROE has a significant effect.

The second hypothesis is H2 = FDR has a significant effect on ROE with a regression coefficient of -0.019 . The estimated FDR variable is $t=-1.003$ and the probability value is 0.340 . Significance value of 0.340 is greater than $0.05, \mathrm{H} 2$ is rejected and FDR to ROE has no significant effect. 
The third hypothesis is that H3 = NPF has a significant effect on ROE with a regression coefficient of 0.39 . The estimation result of NPF variable is $t$ value $=$ 0.784 and a probability value of 0.451 . Significance value of 0.451 is greater than $0.05, \mathrm{H} 3$ is rejected and NPF to ROE has no significant effect.

The third hypothesis is that H4 = BOPO has a significant effect on ROE with a regression coefficient of -0.100 . The estimated BOPO variable is $t=-3,524$ and value probability of 0.005 . Significance value of 0.005 is smaller than 0.05 so H4 is accepted and BOPO of ROE has a significant effect.

b. Simultaneous Test (F statistic) Is testing the regression coefficient overall. This test shows whether all the independent variables included in the model have an influence together against the dependent variable

Following are the results of the simultaneous test:

Table: 7 Simultaneous Test Results

\begin{tabular}{|l|c|c|c|c|}
\hline Model & Sum of & Mean & & \\
& Squares & Square & & \\
\hline Regression & 1,447 &, 362 & 3,624 &, $045^{\mathrm{b}}$ \\
1 Residual &, 999 &, 100 & & \\
Total & 2,446 & & & \\
\hline
\end{tabular}

Source: SPSS data, 2018

Mean of square shows the average variance calculated. For the average per variable seen in the mean of square regression with a value of 0.362 and for the average $\mathrm{Y}$ data variables seen in the mean of square residuals is 0.100 . The table $\mathrm{F}$ value is 3.624 and the calculated $F$ value is 0.45 .

Based on the results of testing the simultaneous test in table 10 it can be explained that a significant value of 0.045 . The significance level is smaller than 0.05 or the $\mathrm{F}$ table value is greater than the calculated $\mathrm{F}$ value, which means CAR, FDR, NPF, BOPO has a significant effect $\mathrm{HO}$ is rejected and Ha is accepted because the variable CAR, FDR, NPF, and BOPO has an effect on simultaneously against ROE. 
Analysis of Financial Ratio on Profitability Level (Return on Equity) in PT. Bank Muamalat Indonesia TBK

\section{c. Coefficient of determination}

The magnitude of the coefficient of determination ranges between 0.00 and 1.00 .

Table: 8 Determination Coefficient Test Results

Summary b model

\begin{tabular}{|c|c|c|c|c|}
\hline Model & $\mathbf{R}$ & Square & $\begin{array}{l}\text { Adjusted } \\
\text { R Square }\end{array}$ & $\begin{array}{l}\text { Std. Error of } \\
\text { the Estimate }\end{array}$ \\
\hline 1 &, $769^{a}$ & 592 & ,428 & ,31601 \\
\hline
\end{tabular}

\section{Source: SPSS data, 2018}

a. Predictors: (Constant), BOPO, FDR, NPF, CAR

b. Dependent Variable: RES2

It is seen that the Adjusted R Square value is 0.428 or $42.8 \%$ which means

CAR, FDR, NPF, and BOPO influence ROE of $42.8 \%$. The remaining $57.2 \%$ is explained by other variables. The error standard of the estimate (SEE) is 0.31601, the smaller the SEE value or close to 0 (zero), the regression model used is more accurate in predicting the dependent variable.

\section{Analysis Of Financial Statements PT. Muamalat Indonesia}

The recording of financial statements of a bank that has been copied to the general public and has been audited by OJK (Financial Services Authority) is divided into several reports other than annual financial reports or Annual Reports, these reports include monthly reports, quarterly reports, GCG reports (Good Corporate Governance), and risk exposure reports.

In this study explained the financial condition of PT. Bank Muamalat Indonesia using annual analysis and quarterly analysis.

\section{Yearly Analysis}

Financial reports that have been processed to look for financial ratios per year produce financial ratios that reflect the financial conditions of PT. Bank Muamalat Indonesia Tbk. The following are the results of the calculation of 
financial ratios which have been averaged based on the first quarter to fourth quarter 2014-2017 reports.

Table: 9 Average Financial Ratios for $2014-2017$

\begin{tabular}{|c|c|c|c|c|}
\hline $\begin{array}{c}\text { TAHUN } \\
\text { RASIO }\end{array}$ & 2014 & 2015 & 2016 & 2017 \\
\hline CAR & $15,057 \%$ & $14,065 \%$ & $12,582 \%$ & $12,45 \%$ \\
\hline FDR & $89,63 \%$ & $92,955 \%$ & $96,842 \%$ & $89,313 \%$ \\
\hline NPF & $6,387 \%$ & $7,505 \%$ & $7,913 \%$ & $6,653 \%$ \\
\hline BOPO & $85,07 \%$ & $89,625 \%$ & $95,087 \%$ & 92,273 \\
\hline ROE & $2,572 \%$ & $2,26 \%$ & $0,85 \%$ & $0,063 \%$ \\
\hline
\end{tabular}

Source: Central Muamalat Bank Data, 2018

In 2014 the financial condition of PT. Bank Muamalat Indonesia Tbk is very good. The capital adequacy value that can be collected is $15,057 \%$ of the total RWA 164 billion including the very healthy category. This means that CAR in 2014 BMI was able to manage its capital very well. However, the FDR and NPF ratios are at the values of $89.63 \%$ and $6.587 \%$. The FDR and NPF values indicate the condition of the rate of return in the sufficient category. BOPO is $85.07 \%$ and ROE is $2.572 \%$. The BOPO value means that BMI is difficult to reduce operating costs and make income decline.

In 2015 the CAR value of $14.065 \%$ decreased due to the decreasing amount of capital so that to overcome the risk of being less good. The value of FDR and NPF which increased quite rapidly were $92.955 \%$ and $7.505 \%$ indicating a low rate of return on financing which triggered a loss at the bank. BOPO value in 2015 amounted to $89.625 \%$ meaning that the increase in the number of operational costs that existed in BMI and ROE in 2015 reached $2.26 \%$ still remained in the unhealthy category.

In 2016 the CAR value declined again with a value of $12.282 \%$ but still in the healthy category. The increase in the value of the ratio is precisely the FDR, NPF, and BOPO which is $96.842 \%$, 
Analysis of Financial Ratio on Profitability Level (Return on Equity) in PT. Bank Muamalat Indonesia TBK

7.913\%, and 95.087\%. This shows a very low reduction in financing returns, giving rise to the number of problematic financing increasing and income from operational costs decreasing. 2016 was only able to achieve investor returns of $0.85 \%$.

2017 to the third quarter became the peak of the financial decline of PT. Bank Muamalat Indonesia. The CAR value reaches $12.45 \%$, FDR is $89.313 \%$, NPF is $6.653 \%$, BOPO is $92.273 \%$, and ROE is $0.063 \%$. All of these ratios are in the unhealthy category, and have an impact on the number of assets decreasing due to the increasing number of problematic financing followed by the increasing number of operational costs.

\section{E. Conclusion}

Based on the results of data analysis and discussion that has been explained in the previous chapter, the conclusions from the research are:

1. $\mathrm{H} 1$ = CAR has a significant effect on ROE received. Based on the results of the $t$ test the significance value of 0.012 is smaller than $\alpha=0.05$. With the results of multiple linear regressions test the regression coefficient value -0.335 which means that if the CAR has a $1 \%$ increase and other variables are constant, the ROE ratio will decrease by $0.335 \%$. Coefficients that have a negative value means that there is a relationship that is not in the same direction. And the results of the classic assumption test state that the CAR variable has a significant effect on ROE with a significant value below 0.05 , which is 0.018 .

2. $\mathrm{H} 2$ = FDR has a significant effect on ROE rejected. Based on the results of the $\mathrm{t}$ test the significance value is 0.340 greater than 0.05 . With the results of multiple regression tests the regression coefficient value is -0.019 , which means that if the value of the other independent variables is fixed and FDR has a 1\% increase, the ROE ratio has decreased by $0.019 \%$.Coefficients that have a negative value means that there is a relationship that is not in the same direction. And the results of the classic assumption test on the Pearson Correlation Test state that FDR against ROE does not have a significant relationship because it has a significant value of $0.719>$ of a significant standard $\alpha=0.05$. 
3. $\mathrm{H} 3=\mathrm{NPF}$ has a significant effect on ROE rejected. Based on the results of the $t$ test the significance value of 0.784 is greater than 0.05 . With the results of multiple regression tests the regression coefficient value is 0.039 , which means that if the value of the other independent variables is fixed and the NPF increases by $1 \%$, the ROE ratio increases by $0.039 \%$. Coefficients that have a positive value means that the relationship is in the same direction. However, the results of the classic assumption test on the Pearson Correlation Test state that NPF to ROE has a significant relationship because it has a significant value of 0.046 smaller than the significant standard $\alpha=0.05$.

4. $\mathrm{H} 4=\mathrm{BOPO}$ has a significant effect on ROE received. Based on the results of the $\mathrm{t}$ test the significance value of 0.005 is smaller than 0.05 . With the results of multiple regression test the regression coefficient value $-0,100$ which means if the value of the other independent variables is fixed and BOPO has increased by $1 \%$, the ROE ratio has decreased by $0.0397 \%$. Coefficients that have a negative value means that there is a relationship that is not in the same direction. And assumption test results the classic Pearson Correlation Test states that FDR against ROE has a significant relationship because it has a significant value of 0.005 with a smaller than significant standard $\alpha=0.01$.

5. Based on the results of testing the simultaneous test significant value of 0.045 smaller than 0.05 or $\mathrm{F}$ count greater than F table, the variables CAR, FDR, NPF, and BOPO have a simultaneous effect on the ROE value.

6. The results of financial statement analysis from the first quarter of 2014 to the third quarter of 2017, explain that the financial condition of PT. Bank Muamalat Indonesia is in the unhealthy category with an average value of CAR $=13.61 \%$, $\mathrm{FDR}=92.37 \%, \mathrm{NPF}=7.14 \%, \mathrm{BOPO}=90.79 \%$, and ROE $=1.52 \%$. this has an impact on the number of assets that are declining due to the increasing number of problematic financing followed by the increasing number of operational costs to make total assets decrease. 
Analysis of Financial Ratio on Profitability Level (Return on Equity) in PT. Bank Muamalat Indonesia TBK

\section{Reference}

Aulia, Farrashita dan Prasetiono, Pengaruh CAR, FDR, dan BOPO terhadap Profitabilitas (Studi Empiris pada Bank Umum Syariah di Indonesia Periode Tahun 2009-2013), Diponegoro Journal of Management Vol. 5 No. 1 Hal. 110,2016

Dahlan, Manajemen Lembaga Keuangan, Edisi Ketiga, (Jakarta: Fakultas Ekonomi Indonesia, 2001) hal. 86

Kasiram, Moh, Metodologi Penelitian, Malang: UIN-Malang Per, 2008.

Kasiram, Moh. Metodologi Penelitian. (Malang: UIN-M

Kasmir, Analisis Laporan Keuangan, (PT. Rajawali Pers, 2008) hal.151

Kasmir, Analisis Laporan Keuangan, (PT. Rajawali Pers, 2014) hal.106

Kasmir, Analisis Laporan Keuangan, Jakarta: PT. Rajawali Pers, 2013.

Kasmir, Analisis Laporan Keuangan. Edisi Satu, Cetakan Ketujuh. (Jakarta: PT Raja Grafindo Persada, 2014) hal. 196

Kasmir, Manajemen Perbankan, Jakarta: PT. Raja Grafindo Persada, 2010

Kasmis, Analisis Laporan Keuangan. Edisi Satu, Cetakan Ketujuh. Jakarta: PT Raja Grafindo Persada, 2014.

Laporan Tahunan 2014 Annual Report "Building Opimism Amidst Market Challenge” PT. Bank Muamalat Indonesia Tbk

Sri Windarti Mokoagow dan Misbach Fuady, Faktor - Faktor yang mempengaruhi profitabiltas bank umum syariah di Indonesia, Jurnal EBANK Vol. 6. No. 1. Hal. 33-62, 2015.

Surat Edaran Bank Indonesia No.12/ 11 /DPNP tanggal 31 Maret 2014 tentang panduan dalam menilai tingkat kesehatan bank dengan analisis Camels

\section{Internet:}

www.bankmuamalat.co.id

www.republika.co.id

www.minnapadi.com

www.google.com/search.Wawan+Prasetyo.Analysis,Affecting+Banking,Profitabilit $\mathrm{y}$,stated,that CAR, did not affect bank profitability. In addition the BOPO 